\title{
QUALITY IMPROVEMENT THROUGH ACCREDITATION AT GRADUATE STUDIES UIN-SU MEDAN
}

\author{
Hasan Asari, Hafsah, Yusnaili Budianti \\ Universitas Islam Negeri Sumatera Utara Medan \\ Jl. Willem Iskandar Pasar V Medan Estate, Medan, Sumatera Utara, 20371 \\ e-mail: hasanasari_nst@yahoo.com,drhafsah@yahoo.com, budiantiyusnaili@gmail.com
}

\begin{abstract}
This article elaborates institutions of quality assurance and accreditation of departments in the context of quality improvement at Graduate Studies of UIN-SU Medan. This qualitative research discovered the following: First, the Quality Assurance Unit of the Graduate Studies, which was established in 2016, has not been operational mainly due to lack of competence of its personnel and insufficient fund. Second, the main hindrances in accreditation process are poor understanding of departments' management, limited support from stakeholders, and insufficient funding. The 'mentoring' of UIN-SU Medan Quality Assurance Office could not have been more helpful and indeed has solved some of the problems. However this practice has not been so useful in developing internal quality assurance culture. Despite the fact that its departments have undergone two to three accreditation procedures, the Graduate Studies has not been successful in delivering a better result.
\end{abstract}

\begin{abstract}
Abstrak: Peningkatan Mutu Melalui Akreditasi Pada Pascasarjana UINSU Medan. Artikel ini menganalisis kelembagaan penjaminan mutu dan pelaksanaan akreditasi program studi dalam konteks peningkatan mutu pendidikan di lingkungan Pascasarjana UIN-SU Medan. Penelitian yang menerapkan prosedur penelitian kualitatif ini menemukan: Pertama, Unit Penjaminan Mutu Pascasarjana yang dibentuk tahun 2016 tidak operasional karena tidak sesuainya kompetensi personel yang ditempatkan serta tidak tersedianya dukungan finansial. Kedua, kesulitan utama dalam proses akreditasi adalah pemahaman pengelola Program Studi tentang akreditasi yang sangat variatif; rendahnya budaya mutu sivitas akademika; dan terbatasnya dukungan finansial. Pendampingan dari Lembaga Penjaminan Mutu UIN-SU Medan sangat membantu. Sayangnya pendampingan ini, meskipun menyelesaikan masalah secara ad hoc tetapi tidak mendukung berkembangnya budaya penjaminan mutu internal yang baik. Dengan berbagai persoalan yang ada, peringkat akreditasi Program Studi di lingkungan Pascasarjana UIN-SU Medan belum mengalami peningkatan meskipun masing-masing Program Studi sudah menjalani dua atau tiga kali akreditasi.
\end{abstract}

Keywords: PTKIN, penjaminan mutu, akreditasi 


\section{Introduction}

The Holy Qur'an puts quality as a top priority. Verse 110 of Sura Ali 'Imrân/3 reads: "You are indeed the best community that has ever been brought forth [the good of] mankind: you enjoin the doing of what is right and forbid the doing of what is wrong, and you believe in God ..." 1

The 'best community/khayra ummat' apparently refers to a very strong quality aspiration. 'Aspiring for the best' as the core message of this verse could be applied into any aspect of Muslim life. Indeed, this verse could be taken as the Statement of Vision and Mission of Muslim life. The vision is "The Best Community" and the missions are "Supporting Rights" and "Forbidding Wrongs".

Throughout history, education has been one of the most important media in achieving this vision. As such, the verse must be taken as a clear indication that Muslims should have education of the highest quality.

It is a rather discomforting reality that Islamic Universities in Indonesia did not develop a systematic quality assurance policy until the beginning of this century. As a rather new practice, the idea of quality assurance has not been welcomed by all stakeholders as it should be. Accreditation process - as one aspect of this quality assurance- - has not received supports it needed. This article elaborates the way in which Graduate Studies of UIN Medan managed its quality assurance through accreditation of its departments. The discussion focuses on quality assurance body and the procedures of accreditation, as well as the way they contribute to quality improvement.

\section{Assuring Quality through Accreditation}

In Indonesian context discourse on education quality gained its momentum following the Reformation waves by the end of the 1990s. This Reformation Era is marked with, among others, strengthening of civil society which necessitates reformation and quality improvement of education. National education quality becomes more important because Indonesian education was inferior compared with that of neighboring countries, such as Singapore, Malaysia, or Thailand.

The comparative quality of Indonesian campuses can easily be understood via University Rankings provided by many bodies. For example, Times Higher Education (THE) University Rankings 2017-2018 includes no Indonesian university. ${ }^{2}$ In Webometrics list, five top ranks

\footnotetext{
${ }^{1}$ Translation is from Muhammad Asad, The Message of the Quran (Gibraltar: Dar al-Andalus, 1980).

${ }^{2 "}$ "Times Higher Education World University Rankings 2018-2019," in https://www.hotcourses. o.id/study/rankings/the-world-university.html, accessed in July 19, 2018.
} 
Indonesian universities are University of Indonesia (ranking 888), Gadjah Mada University (924), Bandung Institute of Technology (1235), Agricultural Institute of Bogor (1462), and Syiah Kuala University (1825). ${ }^{3}$ Meanwhile, Quacquarelli Symonds (QS), in a release called 'QS Asia University Rankings 2018', includes 17 Indonesian campuses in 400 best campuses in Asia. Among them are: University of Indonesia, Bandung Institute of Technology, Bogor Agricultural Institute, Gadjah Mada University, Padjadjaran University, and Hasanuddin University. ${ }^{4}$

Responding to that alarming fact, Indonesian Government takes a number of steps to boost the quality of universities. Among those step was making it mandatory for every campus to have Internal Quality Assurance System and also External Quality Assurance System. This was stipulated in the Law Number 12 of $2012 .{ }^{5}$ The concept of 'quality' was developed into eight aspects of quality standards which are further developed into series of measurable points. ${ }^{6}$

Law 12/12 stipulates that the External Quality Assurance of university should be carried out through accreditation. Accreditation is defined as a "measuring activities based on criteria stipulated by National Standards of Higher Education". 7 A special body called BANPT (National Accreditation Body for Higher Education) is entrusted to develop the standards and manage the who;le procedures of accreditation.

\section{Accreditation Aspects}

BAN-PT allocates the whole evaluation points for accreditation into three forms. First, Department Form, which is further subdivided into seven standards: 1) Vision, Mission, Objectives, Targets, and Strategies of Achieving the Targets (3 points); 2) System, Leadership, Management, and Quality Assurance (6 points); 3) Students and Alumni (14 points); 4) Human Resources (19 points); 5) Curriculum, Learning Activities, and Academic Milieu (29 points); 6) Financing, Facilities, and Information System (16 points); and 7) Research. Community Service, and Cooperation (13 points). ${ }^{8}$

Second, Faculty Form, which is further subdivided into seven standards: 1) Vision, Mission,

${ }^{3}$ http://www.webometrics.info/en/Asia/indonesia\%20, accessed in July 19, 2018.

4“Inilah 17 Kampus Indonesia yang Masuk Peringkat Terbaik Asia," in https://nasional. sindonews.com/read/1249390/144/inilah-17-kampus-indonesia-yang-masuk-peringkatterbaik-asia-1508300973, accessed in July 19, 2018.

${ }^{5}$ Law of Republic of Indonesia Number 12 of 2012 on Higher Education, article 51, 52, and 53.

${ }^{6}$ Law of Republic of Indonesia Number 12 of 2012 on Higher Education, article 4: (1). and (53).

${ }^{7}$ Law of Republic of Indonesia Number 12 of 2012 on Higher Education, article 55: (1)

${ }^{8}$ Badan Akreditasi Nasional Perguruan Tinggi, Akreditasi Program Studi Magister: Buku VI Matriks Penilaian Instrumen Akreditasi (Jakarta: BAN-PT, 2009). 
Objectives, Targets, and Strategies of Achieving the Targets (3 points); 2) System, Leadership, Management, and Quality Assurance (9 points); 3) Students and Alumni (3 points); 4) Human Resources (8 points); 5) Curriculum, Learning Activities, and Academic Milieu (8 points); 6) Financing, Facilities, and Information System (15 points); and 7) Research. Community Service, and Cooperation (10 points). ${ }^{9}$

Third, Department's Self-Evaluation Form, which is further subdivided into four sections: 1) Accuracy and Thoroughness of Information and Data that are used in Self-Evaluation Document (2 points); 2) The quality of analysis in identifying and formulating problems in all components of the Self-Evaluation Document (4 points); 3) Strategies in developing the Department (3 points); 4) Integrity of the Self-Evaluation Document (2 points). ${ }^{10}$

In evaluation process, each point is given a score ranging from 0-4, each representing very poor, poor, good and very good. ${ }^{11}$ It might also be noted that each of the three forms mentioned above contributes differently to the final score: Department Form 75\%, Faculty Form 15\%, and Self-Evaluation Form $10 \% .{ }^{12}$ By the end of an accreditation process, a department will be given accreditation status that falls into one of the following: ${ }^{13}$ Accredited A, with a score range of 361-400; Accredited B, with a score range of 300-360; Accredited C, with a score range of 200-300; and Not Accredited, when total score is smaller than 200.

\section{Steps of Department Accreditation}

In a general sense, an accreditation process involves two separate institutions: 1) the University (Faculty and Department); and 2) the BAN-PT. The latter body has set up an accreditation system and detailed steps that ought to be followed by a university and by BAN-PT itself.

Accreditation steps on the part of university include the following:

1. Setting up an Accreditation Team. In principle, the composition, structure, and the procedure of setting up this Team is an internal policy of a University. Very commonly, this kind of Team includes some lecturers and administration staffs, Head and Secretary of the Department in question, as well as people from the Quality Assurance Office.

2. Preparing the Accreditation Documents. The Accreditation Team starts to prepare the forms following the Guidelines provided by BAN-PT and can be downloaded from its website. As indicated above, there are three forms that must be prepared.

${ }^{9}$ Ibid.

${ }^{10} \mathrm{Ibid}$.

${ }^{11}$ Badan Akreditasi Nasional Perguruan Tinggi, Akreditasi Program Studi Magister, Buku V Pedoman Penilaian Instrumen Akreditasi (Jakarta: BAN-PT, 2009), p. 14.

${ }^{12} I$ Ibid., p. 18.

${ }^{13}$ Ibid. 
3. Submitting the accreditation forms to BAN-PT. This must be done six months before an existing accreditation is expired. By the end of 2017, BAN-PT started an on-line system for Department Accreditation.

4. Preparing for Field Evaluation by BAN-PT Assessors. In this step the Team is expected to give further explanation regarding the real condition of the department.

5. Post Accreditation Evaluation. Once BAN-PT issued the final result of Accreditation, the Accreditation Team analyzes the score to produce complete and detailed information about the strengths and weaknesses of the department. This analysis, in turn, will be used as a consideration in establishing future actions.

Accreditation steps on the part of BAN-PT include the following: ${ }^{14}$

1. Document Assessment. This is performed by two Assessors of BAN-PT based on Book VI Matrix of Document Evaluation.

2. Field Assessment. The two assessors are sent by BAN-PT to visit the Department in order to have a more comprehensive picture. This visit include: discussion between assessors and a department's management; scoring by Assessors; and preparing recommendations.

3. Validation of Field Assessment by Executive Board of BAN-PT and granting the Accreditation. The Accreditation status of a department can be accessed on line via website of BAN-PT.

\section{Accreditation Status of Departments at Graduate Studies UIN Medan}

The Graduate Studies of UIN Medan houses twelve departments, six master programs and six Ph.D. programs. The majority of the departments (9/12) hold Accreditation 'B', two hold Accreditation ' $\mathrm{C}$ ', and one new department has not been accredited. The accreditation scores of those departments with Accreditation 'B' are ranging quite widely from 301 (Ph.D. Department of Islamic Education) to 349 (Master Department of Islamic Education). Indeed, this is pretty far from an Accreditation 'A', which is 361-400. As such, when seen in the context of level and score of BAN-PT, the Departments at Graduate Studies UIN Medan is somewhere between middle and lower middle class.

\section{Quality Assurance at Graduate Studies UIN Medan}

In general, Islamic Higher Education institutions in Indonesia have responded to the need of Quality Assurance, especially when it was made mandatory by formal regulations. Quality Assurance Office in Indonesian Islamic Higher Education is generally known by the following names Quality Assurance Office (LPM) at university level; Quality Assurance Unit (UPM) at faculty level; and Quality Assurance Task Force (GKM) at department level.

${ }^{14} I b i d .$, pp. 15-17. 
The Graduate Studies of UIN Medan established a Quality Assurance Unit in 2016. But, quite disappointingly, this unit has never been in full operation. The main reason is that its personnel do not match the needs of a quality assurance unit. For example, most of the personnel are top-managers and lower staffs of the Graduate Studies. ${ }^{15}$ This very fact is in complete contradiction with the most basic principle of quality assurance, i.e. that the quality assurance body cannot be the same as the one whose quality is to be assured. Another problem is that the majority of the personnel are administrative staffs who cannot fully understand the complicated system of quality assurance. The standards in Accreditation Forms encompass some philosophical aspects (Vision, Mission, and Objectives) and some knowledge aspects (curriculum, learning process, research, and community service)things that should be understood best by teaching staffs. In short, this Quality Assurance Unit has not performed at all. ${ }^{16}$

In past years, the Graduate Studies faced a rather serious hindrance in regard to man power, in that it had no permanent full-time teaching staffs. All teaching staffs were belong to one of faculties and only assigned as part-time instructors at the Graduate Studies. However, this should have been solved by the end of 2015, when the Rector issued a policy of assigning six permanent lecturers to every Department of the Graduate Studies. ${ }^{17}$ As such, lack of man power should have not been a major problem as it had been. The more challenging problem is how to make sure that all these lecturers develop a quality assurance commitment and be prepared to become part of the Quality Assurance Unit.

Director of the Graduate Studies underline another problem that has made the Quality Assurance not operational that is lack of supporting fund. At one point the Graduate Studies tries to retrieve some amount of money from the lecturers' certification allowance to support the Unit. But this becomes harder to do since the money goes directly to lecturers' bank accounts. The final condition, in the words of the Director: "The Quality Assurance Unit is exists de jure, based on the Directors' Decree. But in reality, the Unit is not functioning due to lack of funding." 18

Since the Quality Assurance Unit does not function, head and secretary of departments have to handle all activities related to accreditation. Accreditation process usually starts in a routine meeting in which the Director announces that a particular department is due to prepare for accreditation. This would normally followed by appointing the head of department to start the procedures.

${ }^{15}$ Director's Decree, April 12, 2016.

${ }^{16}$ Interview with Secretary of Department of Islamic Law. No wonder that almost everywhere, the personnels assigned to Quality Assurance Office have always been lecturers, preverably those with some managerial experience.

${ }^{17}$ The latest revision to this Decree is Rector Decree Number 381 of 2018, dated October 08, 2018.

${ }^{18}$ Syukur Kholil, Director of the Graduate Studies, interview, September 2018. 
Some heads of departments complain about lack of information and archives while preparing Accreditation Document. In addition, this is becomes even more challenging when the head of department is newly appointed. This is, for example, brought up by head of Department of Communication and Islamic Propagation. He recalls being appointed head of department in the beginning of 2017 and his department had already been late for accreditation. Not having any past experience in handling accreditation, he had to work with very limited understanding of the procedure and with inadequate support. ${ }^{19}$

Another informant, who is also a head of department, also has the same experience. She stresses the poor condition of records and archives of the department. Every accreditation is very much like a new accreditation. "We have to work absolutely from the beginning." In the same forum, a BAN-PT Assessor underlines the upmost importance of continuous data collection, so that sufficient data should be available when a department is preparing Accreditation Document. ${ }^{21}$

It could be added that in their rather long explanation, two heads of departments never mention any role of the Quality Assurance Unit. But they both express very high appreciation regarding the Quality Assurance Office of UIN Medan for its 'extra ordinary' assistance in accreditation process. This office provides counseling and mentoring in which a department is given an opportunity to present their Accreditation Document draft. The Quality Assurance Office would provide suggestions and corrections to improve the document. The office plays its part all the way until the document is finalized and ready for on-line submission to BAN-PT. ${ }^{22}$ This mentoring activity sometimes called as 'Mengaji Borang' as it frequently appears in lecturers' WhatsApp Group.

In the real sense of the word, it can be said that actually the Graduate Studies has no Quality Assurance Unit. Therefore, accreditation procedures become integral part of the responsibility departments. Heads and secretaries of departments have to handle the whole steps of accreditation: data collection, preparing Accreditation Documents, editing and finishing the documents, collecting supporting documents, as well as handling Field Assessment.

This condition has become a great concern among senior lecturers, especially those who are also BAN-PT Assessors. In fact some suggest that the Graduate Studies should initiate a new permanent unit to handle all matters pertaining to accreditation. This permanent

${ }^{19}$ Ahmad Thamrin Sikumbang, head of Department of Communication and Islamic Propagation, in Focus Group Discussion, August 18, 2018.

${ }^{20}$ Sri Sudiarti, head of Department of Islamic Economy, in Focus Group Discussion, August $18,2018$.

${ }^{21}$ Saiful Akhyar Lubis, BAN-PT Assessor, lecturer of the Graduate Studies UIN Medan, in Focus Group Discussion, August 18, 2018.

${ }^{22}$ Sri Sudiarti, head of Department of Islamic Economy, in Focus Group Discussion, August $18,2018$. 
unit is necessary for at least two reasons. First, it would assure that accreditation process run continuously, well-planned, and in a reasonable time allocation. Second, with the existence of this unit, Department can focus on improving learning process. ${ }^{23}$

\section{Accreditation Procedures}

Accreditation process at the Graduate Studies could be grouped into four stages, i.e. Setting-up Accreditation Team, Preparing the Accreditation Documents, Field Assessment, and Post-Accreditation Responses. The following are important information gathered regarding them:

\section{Accreditation Team}

Every time a department undergoes accreditation the Graduate Studies would set up a Team for Preparing Department Accreditation Documents. Normally, the Director would announce a particular Department is due for accreditation in a regular management meeting. Head of the department is asked to made necessary preparation. Typically, the first step is the department submits to the director a list of names to be appointed Accreditation Team. When the list of names is approved by the Director, head administration prepares the necessary formal document to be sign by the Director.

In the course of this research we have access to no fewer than eight Director's decrees on Teams of Department Accreditation Documents. These eight sample decrees indicate a rather consistent structure: Person in Charge (Director), Coordinator (Vice Director), Head (Head of Department), Secretary (Secretary of Department) and Members (lecturers and administrative staffs). These decrees do not specify clearly the task and targets of each personnel. It simply states that the Team is entrusted with 'planning, preparing, and producing Accreditation Documents of Department." It seems that a general statement of this kind does not respond adequately to the need of continuous preparation of accreditation documents.

\section{Preparation of Accreditation Documents}

Many informants inform that accreditation document preparation is almost exclusively made by the personnel of department. ${ }^{24}$ At some points, they express feelings of being 'abandoned and neglected' in the long tiring process. Only when a document draft is available the Team receives some 'help' from Quality Assurance Office of UIN Medan. Nevertheless, what can be provided by Quality Assurance Office is basically limited to reviewing the document,

${ }^{23}$ Saiful Akhyar Lubis, BAN-PT Assessor, lecturer of the Graduate Studies UIN Medan, in Focus Group Discussion, August 18, 2018.

${ }^{24}$ Sri Sudiarti and Ahmad Thamrin Sikumbang, heads of departments, in Focus Group Discussion, August 18, 2018. 
underlying its weaknesses or mistakes, and suggesting some ways of improvement. This office cannot be hoped to help provide additional data or academic outcomes of lecturers. In spite of that, all informants highly appreciate Quality Assurance Office and the assistance it provides.

It has been mentioned that the biggest challenge in accreditation is the fact that its Quality Assurance Unit has not been able to support departments, especially in providing data. Besides, the knowledge and experience of heads of departments are varying very widely. An informant who is also a head of department informs that he had to prepare accreditation documents just days after his appointment. With no help available, he recalls that it was very confusing and stressful. ${ }^{25}$

One other problem is inadequate commitment of head and secretary of departments towards accreditation matters. Head of Center for Audit and Quality Control, Quality Assurance Office of UIN Medan, relates a fragment of his experience in mentoring department:

"A secretary of a Doctoral Department came to my office along with a junior staff, submitting Accreditation Documents for reviewing, which is by the way long overdue. The documents were brought to Mentoring Forum as planned. After just a while, the secretary decided to leave and delegated the whole business to his younger staff. This particular staff could not be expected to master accreditation problems, as it is not really part of his job description and do not suit his background." 26

This condition is further worsened by very limited participation of stakeholders. A BAN-PT Assessor present in Forum Group Discussion says that he has never been asked to review and make suggestions to improve Accreditation Document at the Graduate Studies, although he is in fact home-based in the Graduate Studies. ${ }^{27}$ Another BAN-PT Assessor says that he was once asked to review and to suggest improvements on a Department's Accreditation Documents. ${ }^{28}$ This condition is perfectly reflected on compositions of Accreditation Teams, mentioned earlier. ${ }^{29}$

Another important finding is that lecturers, despite the fact that they are the backbone of the department, are not involved in accreditation. A lecturer puts it this way:

During my times as a lecturer, I have never been asked to participate [in accreditation]

\footnotetext{
${ }^{25} \mathrm{Ahmad}$ Thamrin Sikumbang, head of Department of Communication and Islamic Propagation, in Focus Group Discussion, August 18, 2018.

${ }^{26}$ Waizul Qarni, head of Center for Audit and Quality Control, Quality Assurance Office of UIN Medan, interview July 27, 2018.

${ }^{27}$ Saiful Akhyar Lubis, BAN-PT Assessor, lecturer of the Graduate Studies UIN Medan, in Focus Group Discussion, August 18, 2018.

${ }^{28} \mathrm{M}$. Yasir Nasution, BAN-PT Assessor, lecturer of the Graduate Studies UIN Medan, interview August 18, 2018.

${ }^{29}$ Director's decrees numbers 210A, 210B, 210C, 211A, 211B, 212A, 213A, and 213B; all on Accreditation Document Teams for different departments.
} 
... I know that I should have been asked to participate, should have been asked regarding, for example, about my syllabi, about my practice, also about what happened in my classes, and so on. I should have been asked, but so far in my capacity as a lecturer, I have never been asked [to participate by the Accreditation Team]. ${ }^{30}$

The same informant stresses that his only form of involvement was the team asked him to submit his academic works; and the request was made only a couple of days before Field Assessment.

A quite alarming information surfaces during the Focus Group Discussion, which is that the majority of lecturers are not supportive enough. It seems that some lecturers still think that their only tasks were handling their classes according to schedules published by the department every semester. Many lecturers fail to understand that a department accreditation, or a university for this matter, depends on the whole system and requires full participation of all lecturers. For example, the scoring system of Accreditation Documents includes many aspects regarding lecturers' performance:

1. Educational background (Master or Ph.D.);

2. Ranks (junior lecturer; senior lecturer; professor);

3. Academic works (books, research reports, scientific articles, etc.);

4. Intellectual Copy Rights;

5. Participation in academic activities (seminars, conferences, workshops, discussions, general lecturers);

6. Membership of an academic or scientific organization;

7. Being a guest lecturer at other universities;

8. Community services.

It is certainly not an easy matter for a department to keep track on these activities and its records. This is particularly difficult because most of lecturers of the Graduate Studies are senior lecturers that usually have high frequency of outside campus activities. A department, in this case, relies mainly on the lecturers' initiatives to report and submit their academic outputs. Quite disappointingly, these badly needed initiatives are not common despite their substantial contribution to accreditation final score. Consequently, as Saiful Akhyar Lubis points out, departments often get poor score on this aspect. ${ }^{31}$

Apparently, serious attempts must be made to enhance the awareness of lecturers regarding their part in accreditation. Lecturers must be aware that their attitude has systemic repercussions. This is a big challenge on the part of the Graduate Studies. However, the expected 2018.

${ }^{30}$ Sulidar, lecturer of Graduate Studies UIN Medan, in Focus Group Discussion, August 18,

${ }^{31}$ Saiful Akhyar Lubis, BAN-PT Assessor, former head of department, and lecturer of the Graduate Studies UIN Medan, in Focus Group Discussion, August 18, 2018. 
results are also very significant. Once the lecturers realize that any reported academic output contributes to accreditation, some of the present problems could be solved. It is also very important to ensure that lecturers are aware that any unreported influence the department in a negative ways. They must be reminded from time to time that according to recent regulations, a non-accredited department is faced with several hindrances and limitations, such as:

1. A non-accredited department is not allowed by regulations to take new students;

2. A non-accredited department is not allowed to convey degrees. So in principle a nonaccredited department is illegal and its management could be persecuted;

3. Many research grants from the government require that the recipient department be accredited 'B' or 'A';

4. Many job opportunities require that a certificate be issued by a department that is accredited 'B' or 'A';

5. Lecturers of a department with an 'A' accreditation are eligible for BAN-PT Assessor recruitment;

6. The community in general takes accreditation as a very serious consideration when choosing campuses.

Departments in Graduate Studies—notably Department of Islamic Law and Islamic Education-has improvised and tried other ways in collecting lecturers' academic outputs. They worked together with Quality Assurance Office UIN Medan to access Lecturer's Workload Report which has to be submitted every end of semester. This strategy is no doubt helpful. However, it must be remembered that this semester-based report does not always represent the full academic activities of lecturers, for at least two reasons. First, Lecturer's Workload Report is usually submitted as part of documents necessary to determine lecturer's extra allowances. Therefore, some activities that are irrelevant in this context are in fact very relevant to Accreditation Documents. These include, for example, involvement in academic organization or becoming visiting professor. Second, differences in expiration time of documents. In practice, lecturers might choose not to report an activity for Lecturer's Workload Report because it is still valid in the next year and a minimum workload has been fulfilled. This is very common in regard to academic works (books, articles, entries, copyrights, etc.) ${ }^{32}$ So, Accreditation Team should not rely solely on Lecturer's Workload Report. In the long run, only strong well-established quality culture could solve series of hindrances faced by the Accreditation Teams.

Another aspect that is often considered to be very challenging is visiting professor. This problem appears to be rooted in several things like funding, willingness of other campuses to welcome a visiting professor, and so on. This is stressed by both Prof. Saiful Akhyar Lubis and Prof. M. Husnan Lubis, the latter was external expert specially invited to the Focus Group Discussion.

${ }^{32}$ Rubrik Penilaian Beban Kerja Dosen UIN SU Medan, tahun 2018. 
Actually, this particular problem has drawn the attention of the government. In August of 2018 the Ministry of Religious Affairs c/q Directorate General of Islamic Education writes to leaders of Islamic Universities across the country offering in-country Sabbatical Leave. ${ }^{33}$ The program includes sending professors from certain campuses to other campuses to work for a month. In its explanation, the objectives of this program are: To increase the quality and competitiveness of Islamic campuses, especially those with no professors; and Disseminating ideas and skills of those professors outside of their campuses. ${ }^{34}$

In this sabbatical leave a professor is expected to do the following:

1. Disseminating ideas and skills in doing research, academic writing, and community services at target campus through different activities to increase the quality and competitiveness of target campus;

2. Producing one book or several articles as result of the activities;

3. Coordinating and communicating with original campuses, target campuses and the Directorate General of Islamic Education regarding the activities;

4. Providing and taking full responsibility about the uses of fund accordingly. ${ }^{35}$

The letter also stipulates that a professor in Sabbatical Leave is relieved from his home duties. This is in addition to financial allowances and housing.

Apparently, this offer, despite its substantive benefits in the context of accreditation, does not receive great interests on the part of campuses and professors. In fact, the Directorate has to extend the registration time for this Sabbatical Leave. ${ }^{36}$ As far as UIN Medan is concerned, no professor applies for this program. In a dialogue with some professors of UIN Jambi, it is discovered that some of the reasons for this poor responses are the following: ${ }^{37}$

1. The announcement of the program appears to be very hasty and allows very limited time for professors to plan. The announcement was made in August and the program was intended to be executed in October

2. The intended output is too demanding considering the available time. It is generally considered impossible to produce "a book draft or several articles" in one month. This is even harder because the professor must also involve in development programs of target campuses.

\footnotetext{
${ }^{33}$ Letter of Director General of Islamic Education, Ministry of Religious Affairs Republic of Indonesia, no. 2542/Dj.I/Dt.I.III.5/HM.01/08/2018, dated August 23, 2018.

${ }^{34}$ Ibid.

${ }^{35}$ Ibid.

${ }^{36}$ Letter of Director General of Islamic Education, Ministry of Religious Affairs Republic of Indonesia, no. 2777/Dj.I/Dt.I.III.5/KU.99.2/09/2018, dated September 10, 2018.

${ }^{37}$ Dialogue with Prof. Dr. A. Husein Ritonga, MA, Prof. Dr. H. Martinis Yamin, M.Pd., Prof. Dr. H. Mukhtar, M.Pd., Prof. Dr. H. Lias Hasibuan, MA, at Graduate Studies UIN STS Jambi, October 27, 2018.
} 
3. There are also concerns and reluctances regarding the intricacies of paper works and reporting stuffs.

4. Most of professors are given additional desk jobs at their own campuses that make it impossible for them to leave for a full month.

In short, despite its potential contribution to campuses developments, Sabbatical Leave program faces many hindrances in execution stage. Professor Martinis of UIN Jambi, who applies for the program, admits that by the end of September 2018 he has not been received any further news from the Ministry of Religious Affairs.

Low quality of Accreditation Documents is also caused by the time available for the team to prepare them. In almost all cases, the Graduate Studies set up Accreditation Teams only months, sometimes weeks, before due date. ${ }^{38}$ Syamsu Nahar emphasizes this timing problem:

I would like to bring up one thing regarding the question of 'what are the most challenging hindrances in preparing Accreditation Documents'... The biggest difficulty is that Rector's order to accelerate the preparation of Accreditation Documents, and be ready by this October [2018]. Meanwhile, we in the department had prepared to start the process in early 2019, because our due date is actually 2020 . As such we have planned to allocate a full year to do the project. But, under the order of Vice Rector we have to present the document to Quality Assurance Office very soon. So, we are having great trouble to have the documents ready in just two months. That is some of the situations we are in. ${ }^{39}$

Based on available Directors' Decrees, coordinating responsibility in preparing Accreditation Documents is entrusted to Vice Director. However, this coordination has not been working well. Many sources express that coordinating here means nothing but "ordering and demanding" on the part of the Director. In reality, much of the coordination function is played by the Quality Assurance Office, as explained above. ${ }^{40}$ One informant, who is a lecturer and was entrusted as head of Department in the past, underline the importance of direct involvement of top managers of the Graduate Studies in preparing Accreditation Documents. Apparently he is a supporter of what often called a 'hand-on management' in this respect.

... To me, in addition to the seven mandatory standards, leadership is also very important ... once again, leadership. This is absolutely important and must be underlined. Leaders must always be alert [about accreditation]. If leaders don't care, nggak peduli, things

\footnotetext{
${ }^{38}$ Saiful Akhyar Lubis, BAN-PT Assessor, lecturer of the Graduate Studies UIN Medan, in Focus Group Discussion, August 18, 2018.

${ }^{39}$ Syamsu Nahar, head of Department of Islamic Education, in Focus Group Discussion, August 18, 2018.

${ }^{40} \mathrm{The}$ fact that Quality Assurance Unit is not functioning is also brought up by the Director. He argues that it is because of lack of personnels and funding. Syukur Kholil, Director, interview, September 2018.
} 
will not work. The process, in colloquial terms should be ditongkrongi [accompanied]. Individuals that are working must be ditongkrongi. ... The presence of leaders is very crucial in assuring the success of accreditation. Money is indeed very important. But money should not be taken as the only success factor. [I remember during my term] we had to work during long nights. But the bosses of that time were with us, showed great attention, we ate dinner together, we had durian fruits together, until the job is completed. [I remember] we never talked about money; we concerned with togetherness to strengthen sense of belonging. So, I think, money is important, but leadership is way more important. ${ }^{41}$

Indeed, funding is a very important aspect in preparing Accreditation Documents. There is strong indication that accreditation has not received attention it needs, especially in budgeting. Ideally, accreditation is a continuous program and substantial amount of fund must be allocated for the purpose every year. As such, every bit of information regarding a department can be accumulated continuously and be available whenever needed. It seems that the absence of regular funding have resulted in many difficulties noted earlier. In regard to funding, we can identify three main problems. First, insufficient amount of money for accreditation of departments. Unfortunately no source was open enough to state the amount of money available for every department. Yet all agree that the amount is very limited and definitely less than needed. In the Focus Group Discussion some suggest that a department needs some Rp100,000,000.00 for an accreditation period. The number seems reasonable considering that an accreditation is normally valid for five years. With that amount of money, a department should be able not just to prepare better Accreditation Documents but also to design some activities that support the Accreditation Documents.

Second, perspectives about accreditation of department. Most lecturers and administrative personnel view accreditation as a single, independent, seasonal activity. This results in the habits of preparing for accreditation only when time is absolutely pressing. This is also result in sudden need of big amount of money for accreditation. Actually, the situation can be avoided if accreditation is seen as a continuous built-in with the whole operations of a department. In this perspective, all activities (and therefore all funds) are perceived and orchestrated to support accreditation.

Third, there are also complaints about the way accreditation fund has been used in Graduate Studies. As has been mentioned above, normally an Accreditation Team comprises of some personnel of department's personnel and some supporting staff. The problem is that the distribution of money does not reflect the contribution of each individual in completing the Accreditation Documents.

The Director of the Graduate Studies informs that he has great difficulty in this respect. He points out that there is a disharmony between the need to fund accreditation properly $18,2018$.

${ }^{41}$ Sulidar, lecturer of the Graduate Studies UIN Medan, in Focus Group Discussion, August 
and some technical administrative regulations regarding money. He often finds himself in a situation where a need to disburse some money is very clear, but he has to back off for not having proper ways of doing so. It has been explained before that the Quality Assurance Unit of the Graduate Studies does not function at all, primarily because of budget problems. ${ }^{42}$

\section{Field Assessment Management}

According to need, BAN-PT sends its Assessors to visit the department being reviewed. It seems that the Graduate Studies of UIN Medan handles this Field Assessment quite separately from Accreditation Documents preparation. As has been mentioned above Director's Decrees about Accreditation Teams do not mention anything about Field Assessment. Assessors coming for this purpose are welcomed and served just like any guest coming to the institution.

Once the Graduate Studies is notified by the BAN-PT, the Director assigns individuals to handle the Field Assessment. This includes picking up the assessors to Kuala Namu International Airport, welcoming ceremony, preparation of meeting venue, preparing necessary records to be presented to assessors, opening ceremony, accommodation, and so on. It seems that the most challenging aspect of Field Assessment is preparing and presenting academic outputs of lecturers. The reasons for the situation are many, some on the part of the department others on the part of lecturers. The fact that Accreditation Documents are generally prepared in a hasty manner is certainly related to this.

One other problem in that not too many lecturers are willing to attend the Field Assessment. When asked about this, some reasons come to surface: 1) lecturers do not consider accreditation and field assessment as their concern, it is solely the responsibility of the heads and secretaries of departments; 2) no invitation from departments; 3) having other things to do on the ' $\mathrm{d}$ ' day. ${ }^{43}$ The presence of lecturers during a field assessment is actually very important. It shows the team spirit of the department in question and demonstrates that every single individual would like to contribute to its development. It is no secrets that BAN-PT Assessors highly appreciate the presence of lecturers because it demonstrates the effectiveness of department's managements and participation of department's stakeholders. This is also true about the presence of students, alumnae, as well as the users of alumnae.

A Field Assessment seems to need a kind of personal touch, because it includes direct personal encounters with Assessors. A very experienced informant stresses the importance of handling Assessors well and makes them feel at home. He argues that it is important to know the cultural background of Assessors and to treat them accordingly whenever possible. For example, ethnic and regional origins usually define taste and food preference, manners in speaking, and so on. These must be taken into consideration. The informant observes

\footnotetext{
${ }^{42}$ Syukur Kholil, Director of the Graduate Studies, interview, September 2018.

${ }^{43}$ Lecturers, opted not to be mentioned by names, interviews, September to October 2018.
} 
that UIN SU had had some bad experience in this respect. However, he also point out that some substantial improvements have been made in recent times. ${ }^{44}$

\section{Post Accreditation Procedures}

Normally, BAN-PT issues the final result of accreditation around one month after Field Assessment. A department is supposed to do some procedures in response to the result, whatever the result might be. A special meeting involving stakeholders is generally needed to formulate the steps that are to be taken afterwards. This kind of meeting usually comes up with the following:

1. An exhaustive list of strengths and weaknesses of the department based on standards and points in Accreditation Documents.

2. The list should be further interpreted into an Action Plan to strengthen the department. Existing weaknesses should be analyzed to produce a priority list. Existing strengths are to be maintained and enhanced.

3. Designing specific remedial steps which should be included in the upcoming year's programs.

4. Ways of controlling and supervising the programs in the coming years.

It is a rather sad fact that the Graduate Studies of UIN Medan has never done any formal meeting that is specifically held to respond an accreditation result. As a matter fact, the idea seems to be alien to some of its personnel. During the FGD, some heads of departments reluctantly admit that such meeting has never been held. Also, no head of department present at that time was aware of the exact accreditation score of their own department. ${ }^{45}$

Actually, the spirit to improve accreditation score is displayed very strongly in the Graduate Studies. This can be felt in conversation and formal addresses by the managers. ${ }^{46}$ It is also shown via very expressive banners displayed every time an accreditation result is announced by BAN-PT. During the course of this research, no fewer than three banners were hung on the eastern walls of the inner court of the Graduate Studies: "Congratulations, Department of Islamic Law is accredited 'B' aspiring for 'A'..... Graduate Studies, Excellent!," "Congratulations, Department of Islamic Education is accredited 'B' aspiring for 'A'..... Graduate Studies, Excellent!," and "Congratulations, Department of Communication and Islamic Propagation is accredited 'B' aspiring for 'A'..... Graduate Studies, Excellent!”

\footnotetext{
${ }^{44}$ Saiful Akhyar Lubis, BAN-PT Assessor, lecturer of the Graduate Studies UIN Medan, in Focus Group Discussion, August 18, 2018.

${ }^{45}$ Syamsu Nahar and Ahmad Thamrin Sikumbang, heads of departments, in Focus Group Discussion, August 18, 2018.

${ }^{46}$ For example, accreditation received special mentions in the Director of the Graduate Studies' opening adress in Lecturers Meeting, August 30, 2018.
} 
There is no doubt that all stakeholders support this idea, albeit theoretically. Theoretically, because, so far, the spirit has not been translated into a feasible road map delineating the problems and specifically shows the steps to be taken, suggests the strategies, and explains who-does-what.

By saying that, we do not mean that no one is aware of the problems. Students and lecturers point out that over capacity due to over recruitment of undergraduate students has influenced the Graduate Studies, because some of undergraduate students are using the facilities of Graduate Studies. Many learning facilities are not working properly (e.g. air conditioners, power outlets, In-Focuses, white boards) ${ }^{47}$ Complains about this have been brought up repeatedly in meetings and also via WatsApp Group of Graduate Studies lecturers. So far, real steps to solve the problems are to be seen.

\section{Preliminary Ideas for Improvement}

Apparently many steps need to be planed and taken to ensure that departments of Graduate Studies improve steadily into the future. The following are some practical ideas that might be considered:

\section{Disseminating and Strengthening Quality Culture}

Apparently departments of the Graduate Studies are facing serious problem concerning quality culture. Not all stakeholders take quality assurance procedures equally serious. Some still think that quality assurance is solely the responsibility of the Director and heads of departments. To solve these problems, a series of socialization meetings involving management and lecturers are needed. In these meetings head of department informs all the real condition of the department in the context of quality assurance and accreditation. All lecturers need to understand that they share the responsibility of department's quality; and as such their supports and involvements are absolutely necessary. Lastly, all must be made aware that failure to have a department accredited has very wide repercussions, including legal status of the department.

Continuous socialization should in turn develop a good quality culture among stakeholders. By quality culture we mean a condition where all stakeholders voluntarily and enthusiastically contribute to improve the quality of department they work for. This includes high academic productivity on the part of lecturers. Lecturers with high quality culture perceive their works not just as personal achievement but also as a way of supporting their department. As such they would voluntarily keep record of their academic activities and willingly submit them to the department should it be needed.

\footnotetext{
${ }^{47}$ Neliwati (alumnie/lecturer), Suaidi Rangkuti, Fakhrurrazi, Arief Darmawan (students) in Focus Group Discussion, August 18, 2018.
} 
Quality culture can be improved if the Graduate Studies provides substantial grants for lecturers to hold projects that are relevant to accreditation. It must be noted that the Graduate Studies has been for years provide fund for lecturers to publish their books. Recently there is also a very welcomed assistance for lecturers to apply for Intellectual Copyright Certificate (HAKI). These are good examples of programs which directly help departments in preparing $\mathrm{AD}$ and, in the long run, help establish a better quality culture. Implementation of 'reward and punishment' is also an effective strategy to set up a strong quality culture.

\section{Strengthening Quality Assurance Bodies}

One other strategic step is strengthening quality assurance bodies: Quality Assurance Unit of Graduate Studies as well as Quality Control Taskforces of departments. A strong Quality Assurance Unit is absolutely crucial in this respect, as has been argues earlier. There are at least three points that need to be remembered in improving the Quality Assurance Unit: 1) Total number of personnel. The Quality Assurance Unit needs to have reasonable number of personnel, considering its big number of departments and students. 2) Competence of personnel. Quality assurance and accreditation require wide range of knowledge and know-hows. That must be adequately responded in the appointment of personnel. In general, lecturers are more suitable to fill the posts although some technical staff is also required. It is also important to make sure that quality assurance personnel should not be the managers of departments, since this practice is not in accordance with the principle of division of job and responsibilities. 3) Structural supports. In accordance with recent regulation and future orientation the Graduate Studies has no option but to provide strong support to its Quality Assurance Unit. This support should include authorities, staffing, funding, facilities, and appreciation. In short, the unit must be taken absolutely seriously by the management of the Graduate Studies.

\section{Accreditation-Based Programs}

The Graduate Studies needs to make sure that its future programs respond positively to accreditation needs. Some of the existing programs are already in line with this principle, as mentioned above. These only need to be continued and improved in volume and quality standard. Others need to be newly designed. For example, some improvisations are needed to make visiting professor feasible. Limited fund can actually be solved by having cooperation with other graduate studies in form of exchanging professors.

\section{Improving Reporting and Archiving System}

The difficulty in collecting academic records during accreditation can be reduced by having a better reporting and archiving system in place. This include, for examples: 1) better coordination and communication between departments and lecturers; 2) departments 
require lecturers to provide their academic records frequently and some kind of rewardand-punishment mechanism is applied according to lecturers' compliance; 3) departments set up a storage system that is based on $\mathrm{AD}$; and 4) departments coordinate with Quality Assurance Unit to acquire lecturers' workload reports.

\section{Improving Accreditation Documents Preparation}

Problems related to Accreditation Documents preparation can be improved through many steps, including the following: 1) quality assurance should be perceived in a more comprehensive way and should not be reduced into AD only. In fact the preparation of Accreditation Documents becomes very difficult because it is cut off from the rest of steps, such as planning, reporting and archiving system; 2) a more sensible scheduling; 3) involvement of more parties in Accreditation Team; 4) mentoring from highly experienced person, preferably a BAN-PT Assessor which include marking and field assessment simulation.

\section{Post-Accreditation Procedures}

Regarding post-accreditation procedures, a specially designed formal meeting must be held to respond to every result of accreditation process. This meeting is intended to accomplish: 1) a detailed list of strengths and weaknesses of a department in the context of BAN-PT standards; 2) a detailed list of ways in which strengths will be further improved and weaknesses fixed; 3) feasible strategies to ensure that the problems is to be handles in the coming year's programs. This kind of meeting ahould become part of accreditation program.

\section{Conclusion}

It is absolutely clear that UIN Medan is gearing up in quality assurance practices. However, as of now, it is still very far away from the league of Indonesian universities that managed to attain international recognition. This analysis contains itself on data retrieved from the Graduate Studies only. The problems of quality assurance in this unit are very complex, ranging from poor understanding of quality assurance to lack of technical know-hows; from absence of Quality Assurance Unit to insufficient funding and shortage of personnel; from poor coordination and communication among stakeholders to low sense of responsibility on the part of some lecturers.

As such the Graduate Studies needs to take some rather radical approaches and steps in order to improve its accreditation and overall quality. The approaches must respond to the complexity of the existing problems and hindrances. The steps to be taken have to have the potential to reduce, if not solve, the problems. The high spirits as recorded in banners and 
expressed in speeches badly need proper, feasible programs and strategies. These banners and slogans need to be brought down into actions!

\section{References}

Asad, Muhammad. The Message of the Quran. Gibraltar: Dar al-Andalus, 1980.

Ashcraft, K. and L.F. Peek. The Lecture's Guide to Quality and Standards in Colleges and Universities. London: The Falmer Press, 1995.

Badan Akreditasi Nasional Perguruan Tinggi. Akreditasi Program Studi Magister: Buku VI Matriks Penilaian Instrumen Akreditasi. Jakarta: BAN-PT, 2009.

Badan Akreditasi Nasional Perguruan Tinggi. Akreditasi Program Studi Magister, Buku V Pedoman Penilaian Instrumen Akreditasi. Jakarta: BAN-PT, 2009.

BAN-PT. Guidelines for External Accreditation of Higher Education. Jakarta: BAN-PT, 2000.

BAN-PT. Guidelines for Internal Quality Assessment of Higher Education. Jakarta: BAN-PT, 2000.

BAN-PT. Pedoman Evaluasi-diri Program Studi. Jakarta: BAN-PT, 2008.

Buku Panduan Akademik Program Doktor Pascasarjana Universitas Islam Negeri Sumatera Utara Medan 2017/2018. Medan: Pascasarjana UIN SU Medan, 2017.

Buku Panduan Akademik Program Magister Pascasarjana Universitas Islam Negeri Sumatera Utara Medan 2017/2018. Medan: Pascasarjana UIN SU Medan, 2017.

Buku Propil Lembaga Penjaminan Mutu Universitas Islam Negeri Sumatera Utara tahun 2017

Council for Higher Education Accreditation (CHEA). Recognition of Accrediting Organizations Policy and Procedures. CHEAD Document approved by the CHEA Board of Directors, September, 28, 1998.

National Accreditation Agency for Higher Education (BAN-PT). Guidelines for External Quality Assessment of Higher Education. Jakarta: Ministry of National Education (Depdiknas), 2000.

National Accreditation Agency for Higher Education (BAN-PT). Guidelines for Internal Quality Assessment of Higher Education. Jakarta: Ministry of National Education (Depdiknas), 2000.

National Council for Accreditation of Teacher Education, 1997. Standards, Procedures, and Policies for the Accreditation of Professional Education Units. Washington, DC: NCATE.

Peraturan Menteri Pendidikan dan Kebudayaan Nomor 49 Tahun 2014 tentang Standar Nasional Pendidikan Tinggi.

Tadjudin, M.K. Asesmen Institusi untuk Penentuan Kelayakan Perolehan Status Lembagayang Mengakreditasi Diri bagi Perguruan Tinggi: Dari Akreditasi program Studi ke Akreditasi Lembaga Perguruan Tinggi. Jakarta: BAN-PT, 2000.

Tim BAN-PT. Sistem Akreditasi Pendidikan Tinggi. Naskah Akademik. Jakarta: BAN-PT, 2003. 
MIQOT Vol. XLII No. 2 Juli-Desember 2018

Undang-undang Negara Republik Indonesia Nomor 12 Tahun 2012 tentang Pendidikan Tinggi.

Universitas Islam Negeri Sumatera Utara. Medan: UIN SU Medan, 2015. 